\title{
Competitiveness Improvement Strategy of Soybean Commodity: Study of Food Security in East Java - Indonesia
}

\author{
A. Zainuri ${ }^{1}$, A. Wardhono ${ }^{1}$, Sutomo $^{2}$, J. A. Ridjal ${ }^{3}$ \\ ${ }^{1}$ Department of Economics, Faculty of Economics, University of Jember, Indonesia \\ 2 Department of Administrative Science, Faculty of Social and Politic Science, University of Jember, \\ Indonesia \\ ${ }^{3}$ Department of Agribusiness, Faculty of Agriculture, Unviersity of Jember, Indonesia
}

\begin{abstract}
The increase in soybean prices is caused by an imbalance between the ability to produce soybeans in the country and the increase in demand, so that scarcity of soybean is an issue in an agricultural country like Indonesia. The purpose of this study was to determine the mapping and competitiveness of soybean in East Java, as well as to find out alternative government policies to increase the fair competitiveness of soybean in East Java. Based on the results of the analysis, the recommendation on the most effective policy is the development of competitiveness of local soybean and maintaining the performance of the existing farmer groups, as well as the stabilization of local soybean prices.
\end{abstract}

\section{Key words}

Competitiveness, food security, government policy, soybeans.

JEL Code: Q02, Q11, Q18

\section{Introduction}

Price fluctuations of soybean commodity become a crucial issue in Indonesia each year. Empirically the increase in soybean prices is caused by the element of scarcity on the supply side, or domestic soybean production is slower compared to the demand (Elizabeth, 2007; Zakaria et al, 2010; Eden et al, 2012). The imbalance between the ability to produce soybeans and the increase in domestic demand has actually occurred within a fairly long period (Adisarwanto, 2008; Nuryanti, Kustiari, 2007). The empowerment efforts to increase soybean production require reorientation on strict and problem-facing policies, for example through the intensification, extensification, and integrated soybean crop diversification (Sumarno, 2010; Suradisastra, 2008). In addition, it is necessary to carry out and in-depth study of the determination of policies to enrich the knowledge of the various factors that influence farmers' decisions grow soybeans.

Trade liberalization provides new opportunities and challenges in the development of an agricultural commodity, including soybean (Ahmad, Tawang, 1999; Firdaus et al, 2012).
The new opportunities are because the increasingly larger market and the elimination of trade barriers between countries (Lee, Swagel, 1994). The significance of the impact of trade liberalization will also cause problems if the commodity produced is not able to compete in world markets. In this regard, it is necessary to study in depth the institutional arrangement of soybean farming since the farmers' declining motivation for planting soybean is presumably affected by market actors' agreement and regulations that have no direct positive impacts on soybean farmers (Rante, 2013; Huang, Rozelle, 2004). Thus, the farmers feel that they get less even no protection from external conditions. The purpose of this study was to determine the mapping and competitiveness of soybean in East Java and to find out alternative government policies to increase the fair competitiveness of soybean in East Java.

\section{Review of literature}

Empirical study brings the framework of understanding of the problems of soybean in Indonesia with a variety of conclusions. Handayani et. al. (2009) studying the policy simulation of local soybean competitiveness 
in domestic markets argue that the strategies used in improving competitiveness and domestic soybean production through increasing productivity by implementing farming technology and extending the planting area to increase cropping index. However, the productivity improvement program must also be accompanied by price protection policy by the government to strengthen the competitiveness of domestic soybeans (Song et al, 2009). In contrast, Rante's study (2013) which analyses the soybean crop development strategies for the economic empowerment of rural people in Keerom Regency recommends the financial feasibility of local soybean farming. Strategies used in increasing production of local soybean and processing industry development on the basis of local soybean by the capital assistance of either bank or non-bank financial institutions (Sudaryanto et al, 2001).

The study by Zakaria et al (2010) on the analysis of the competitiveness of soybean commodity based on agro-ecosystem: cases in three provinces in Indonesia show that soybean farming still has a sufficient competitive advantage as an import substitution commodity. The decline in soybean production is prompted by the low participation of farmers in planting soybeans due to lack of motivation and ability of farmers to manage their farming (Budhi, Aminah, 2010). Meanwhile, to increase the participation of farmers in soybean farming, it is important to overcome obstacles such as lack of quality seeds, farmers' fairly high risk and the absence of incentive for appropriate soybean selling prices.

\section{Materials and methods}

\section{Types and sources of data}

Sources of data in this study consisted of primary data and secondary data. The primary data were obtained through empirical studies on a number of economic actors using in-depth interview technique. Secondary data were obtained through written reports of related institutions, literature collection, and papers relating to the existing problems and supporting the primary data.

\section{Research location and analysis unit}

The study was located in East Java, and the research objects were determined by multi-stage cluster sampling on soybean production centres, such as Banyuwangi and Jember. The unit of analysis of this study was representatives of soybean farmers, soybean trade actors, and stakeholders from the concerned government agencies, especially agriculture department in each selected district.

\section{Method of data analysis}

The methods used in analysing the mapping and competitiveness of soybeans as well as alternative government policies to increase the fair competitiveness of soybean in East Java fair consisted descriptive analysis method and causal analysis method. Descriptive analysis was obtained from in-depth interviews aimed to portray the competitiveness of soybean. A comprehensive description of the research objects is supported by the results of the analysis using Force Field Analysis (FFA) method which is able to strengthen the results of previous descriptive analysis.

FFA is developeed by Lewin (1951) and is used broadly to inform about decision making especially in planning and running management program in an organization. This analysis is a good method to gain comprehensive pictures of all power on main issues of policy. It also predicts sources and power level of the policy. First step on FFA is dealing with changing field agreement which will be discussed. The changing field can be written as the goal of policy which is needed by the researcher. Next step is determining what kinds of effort to overcome the power. The most significant effect will be gained by increasing weak supported- power while decreasing strong inhibitors.

\section{Results sand discussion}

Development of competitiveness of soybean commodity

The development of soybean competitiveness can be determined by analysing the driving and inhibiting factors using Field Force Analysis. The results of FFA will bring policy recommendations that minimize the inhibiting factors by optimizing the driving factors toward the goal to be achieved. Based on in-depth interviews, there are six driving factors and six inhibiting factors in the development of soybean competitiveness. The explanation of the driving factors and inhibiting factors can be seen in Table 1 .

The driving factors in the development of soybean competitiveness can be defined as things that become strengths and opportunities. These factors 


\begin{tabular}{|l|l|l|l|}
\hline No. & Driving factors & No & Inhibiting factors \\
\hline D1 & The existence of farmer groups & H1 & Soybean prices are uncertain \\
\hline D2 & $\begin{array}{l}\text { Partnership with Bulog (Logistic } \\
\text { enterprise }\end{array}$ & H2 & There is no cooperative \\
\hline D3 & Land suitability for cultivation & H3 & $\begin{array}{l}\text { Lack of support of banking/credit } \\
\text { institutions }\end{array}$ \\
\hline D4 & Seedling by farmer groups & H4 & Limited extension and training to farmers \\
\hline D5 & $\begin{array}{l}\text { The need of soybean for agroindustry is } \\
\text { always stable }\end{array}$ & H5 & $\begin{array}{l}\text { Helplessness of farmer groups in facing } \\
\text { middlemen }\end{array}$ \\
\hline D6 & Availability of production facilities & H6 & Limited market information \\
\hline
\end{tabular}

Source: Field survey 2013

Table 1: Driving factors and inhibiting factors of soybean competitiveness.

will be determined to be the key power to success in the development of soybean competitiveness. These factors are as follows:

1. The existence of farmer groups. Famer group is a body of farmers based on similarity, harmony of one socio-cultural environment to achieve the same goal. Farmer group is a means for farmers to obtain additional information on good cultivation of soybean crops. The existence of farmer groups also facilitates the coordination of farmers regarding the assistance provided by the government in the form of seeds, fertilizers, and drugs. Through cooperation within and between farmer groups it is expected expected that the activities performed are in better coordination, efficiency and ability to deal with threats, challenges, obstacles and interferences in the future.

2. The existence of partnership with Bulog. Partnership with Bulog is a supporting factor in the development of soybean competitiveness. The partnership that exists between soybean farmers and Bulog will further increase farmers' motivation to increase production and will certainly add the interest of other farmers to do soybean farming because of the certainty of goods produced to be bought by Bulog; in addition, the price is agreement of farmers and Bulog.

3. Land Suitability for Cultivation. Land suitability for cultivation becomes a special value for soybean planting because not all locations can be planted soybean plants. Soybean which is actually sub-tropical climate a plant is developed in Indonesia by adjustment to be planted in the tropical climate of Indonesia. Land suitability for the soybean crop in Banyuwangi and Jember makes the two towns be one of the soybean producing centres in East Java. The land suitability should be used as a motivation to the farmers especially in Banyuwangi and Jember to increase the acreage of soybean plants.

4. The self-seeding by Farmer Groups. Self-seeding by farmers becomes a supporting factor for developing soybean competitiveness. Seeding done by farmer groups also becomes cooperation between farmers and Bulog. Seeds produced by seeding managed by farmer groups will be sold to Bulog (a government body). The seeds will be given back to the farmers in the form of assistance for the coming soybean planting season. The seeding shows that the existing farmer groups has been developed in thought because it not only focuses on the cultivation and sale but also thinks about the coming planting by self-seeding.

5. The need of soybeans for agro-industry is always stable. The need of soybeans to meet agro-industry demands is the supporting factor in the development of soybean competitiveness. Farmers do not worry about performing soybean production due to the certainty of soybean sale produced for agro-industries, especially tofu agro-industry. The stable need of soybean can trigger farmers to continue to farm soybeans adapted to the condition of the area. However, the soybean prices 
which are unstable or tend to decrease when the harvest time should be government's concern to stabilize the price of soybeans in the harvest time.

In addition to the driving factors, the development of soybean competitiveness also needs to consider the inhibiting factors in which the factors can be defined as things that become the weaknesses and threats in improving the product competitiveness. These factors are as follows:

1. Uncertain selling price of soybean. The selling price uncertainty is absolutely the major inhibiting factor which makes the low competitiveness of soybean. The uncertainty of the selling price of soybean is caused by several things such as the quality of local soybean, the amount of imported soybeans, the availability of soybean domestic supply, soybean price played by middlemen or traders and number of related market chains in the marketing process of local soybeans. The fluctuating or unstable selling prices of soybeans can cause farmers' reluctance to continue soybean plant cultivation.

2. Non-existence of cooperatives. The existence of cooperating in a farming group can serve as a provider of precise production facilities and a marketing channel where farmers can sell their yields at a reasonable price. This is what is not available in most of the soybean farmer groups in East Java. The nonexistence of cooperative institutions makes soybean farmers find it difficult particularly in marketing. Most of the soybean farmers sell their produce to middlemen at very low prices, so it is not in balance with what they performed.

3. Lack of support from credit/banking institutions. One of the highly-needed factors by soybean farmers in soybean farming is capital. In running the soybean farm, they certainly large amount of capital. Soybean farmers who basically earn low incomes often experience difficulties in terms of capital. The credit/banking institution which is one of capital providers gives very little support to soybean farmers. This lack of support is mostly because of lack of trust from the institution to soybean farmers.

4. Limited extension and training to farmers. Extension and training are basic necessities to soybean farmers in order to improve his farming. Limitation or lack of active extension workers to soybean farmers leads to the weakening competitiveness of soybean. Without training and extension in soybean farming, farmers find it difficult to absorb information and adopt modern technology, so that they seem to run the farm conventionally.

5. The helplessness of farmer groups to face the middlemen. Middleman plays the price arbitrarily. This is because most of the farmers sell their produces to middlemen, so the soybeans cultivated by farmers do not have high bargaining power. The mechanism of soybean selling by farmers to middlemen is often done by tebas system where the middlemen go directly to the farmers who are harvesting. Farmers who are basically still conventional-minded will certainly sell their produce directly without thinking of other possibilities if the results are processed or sold to any other parties other than the middlemen.

6. Limited market information. Farmers who sell their produces obtain information on the market, such as the selling price of soybeans, only from a single source, that is, the middlemen. Middlemen determine the prices of farmers' soybeans based on the selling back to wholesalers. The system has surely inflicted a financial loss for soybean farmers because they cannot compare soybean prices with the other regions. It takes an active role of agricultural institutions such as farmer groups in order that market information can be absorbed well by the farmers so that the bargaining power of the cultivated soybean is higher.

Identification was continued to assessment of the driving factors and the inhibiting factors of soybean competitiveness. The results of the assessment would result in the values that can be used in formulating appropriate policy recommendations. The assessment conducted in the process of FFA analysis was a qualitative assessment quantified at the scale values of 1-5. The assessment was through brainstorming of the respondents who were experts in the improvement of local soybean competitiveness. The results of the assessment 
are included in the evaluation table of the driving and inhibiting factors.

Based on the FFA analysis in the evaluation of the driving factors and inhibiting factors as listed in the table of driving factors and inhibiting factors, the value of Total Value Weight (TNB) of each factor can be identified. Based on the total value weight, Key Success Factors (FKK) in the development of local soybean competitiveness in East Java can be determined by considering the highest weight value. Key success factors (FKK) are divided into two, namely driving FKK and inhibiting FKK. Below is the table of evaluation of the driving factors in the improvement of soybean competitiveness in East Java.

Based on Table 2 above, it is recognized that the driving FKK with the highest value is D1 (the existence of farmer groups) gaining a total value weight of 1.57 . The farmers' group can motivate farmers to increase the production of farm produces. In the process of soybean farming, farmer groups take a role as one of the providers and distributors of production facilities such as soybean seeds, fertilizers, drugs or farming devices that support soybean farming activities (Wahyuni, 2003; Reimer et al, 2009). Farmers' group also has a role in marketing. Despite its small role, the existence of the farmers' group also has an important role as the source in the delivery of market information such as soybean price to farmers. The highest value support (ND) in Table 2 is also on the first driving factors, namely the existence of farmer groups (D1) and adequate availability of production facilities (D6). This shows that both factors are the most relevant factors in supporting the development of soybean competitiveness, particularly in East Java. In addition to driving factors, there are inhibiting factors that hinder the development

\begin{tabular}{|c|c|c|c|c|c|c|c|c|}
\hline No. & Driving factors & BF & ND & NBD & NRK & NBK & TNB & FKK \\
\hline D1 & The existence of famer groups & 0.29 & 5 & 1.47 & 3.91 & 1.15 & 2.62 & $* 1$ \\
\hline D2 & Partnership with Bulog & 0.12 & 4 & 0.47 & 2.91 & 0.34 & 0.81 & 6 \\
\hline D3 & Land suitability for cultivation & 0.18 & 4 & 0.71 & 2.91 & 0.51 & 1.22 & 3 \\
\hline D4 & Seeding by farmer groups & 0.12 & 4 & 0.47 & 3.27 & 0.39 & 0.86 & 5 \\
\hline D5 & $\begin{array}{l}\text { The soybean need for agroindustry } \\
\text { is always stable }\end{array}$ & 0.24 & 3 & 0.71 & 3.18 & 0.75 & 1.45 & 2 \\
\hline D6 & Availability of production facilities & 0.12 & 5 & 0.59 & 3.64 & 0.43 & 1.02 & 4 \\
\hline
\end{tabular}

Notes:

*): Priority (FKK)

BF: Weight Factors

ND: Value Support

NBK: Weight Value Linkage

TNB: Total Value Weight

NRK: Average Value Linkage

FKK: Key success factors

Source: Field survey 2013

Table 2: Evaluation of driving factors in the improvement of local soybean competitiveness in East Java.

\begin{tabular}{|c|c|c|c|c|c|c|c|c|}
\hline No. & Driving factors & BF & ND & NBD & NRK & NBK & TNB & FKK \\
\hline H1 & Uncertainty of soybean selling price & 0.28 & 5 & 1.39 & 2.82 & 0.78 & 2.17 & $* 1$ \\
\hline $\mathrm{H} 2$ & No cooperatives & 0.22 & 4 & 0.89 & 3.27 & 0.73 & 1.62 & 2 \\
\hline $\mathrm{H} 3$ & $\begin{array}{l}\text { Lack of support from credit/banking } \\
\text { institutions }\end{array}$ & 0.11 & 3 & 0.33 & 2.18 & 0.24 & 0.58 & 6 \\
\hline $\mathrm{H} 4$ & $\begin{array}{l}\text { Limited extension and training } \\
\text { to farmers }\end{array}$ & 0.11 & 3 & 0.33 & 2.73 & 0.30 & 0.64 & 5 \\
\hline $\mathrm{H} 5$ & $\begin{array}{l}\text { Helplessness of farmer groups } \\
\text { to face tengkulak (middlemen) }\end{array}$ & 0.17 & 4 & 0.67 & 2.64 & 0.44 & 1.11 & 4 \\
\hline H6 & Limited market information & 0.22 & 4 & 0.89 & 2.91 & 0.65 & 1.54 & 3 \\
\hline
\end{tabular}

Notes:

*): Priority (FKK)

Source: Field survey 2013

Table 3: Evaluation of inhibiting factors in the improvement of local soybean competitiveness in East Java 
of agro-industry. Below is the table of evaluation of the inhibiting factors in the improvement of soybean competitiveness in East Java.

Based on Table 3, it can be identified the inhibiting FKK in the improvement of soybean competitiveness in East Java, namely $\mathrm{H} 1$ factor (uncertainty of soybean selling price) with the total value weight or the urgency factor of 2.17 . The uncertainty of soybean selling price is a vital thing for farmers and agro-industry actors. For farmers, the uncertainty of soybean selling price will surely affect the sustainability of farming activities. The fluctuating price of soybeans will make soybean farmers who basically grow local soybean plants find it difficult to compete with imported soybeans which are nowadays widely used as raw materials by the agroindustry actors (Graham et al, 2010; Zakaria et al., 2010). The highest ND in the inhibiting factors is also available in the first factor, that is, not the uncertainty of soybean selling price. This shows that the factor is closely related in the development of the soybean competitiveness, particularly in East Java. The level of TNB of each driving and inhibiting factor can be visualized in a diagram called force field diagram with the condition to be achieved. Whereas, the force field of the driving factors and inhibiting factors in the development of soybean competitiveness in East Java is presented in figure 1 below.

The figure 1 shows that the highest driving factor is D1, that is, farmers' motivation, and the highest inhibiting factor is $\mathrm{H} 1$, that is, Uncertainty of soybean selling price. The total number of BNP of driving factor is 7.98, and that of inhibiting factor is 7.64. This shows that the total value of TNB of driving factor is higher than that of TNB of inhibiting factor, which means that the local soybean still has the advantage to improve the competitiveness.

It is explained that the results of FFA analysis will bring a policy recommendation that minimizes the inhibiting factors by optimizing the driving factors toward the goal to be achieved. Formulation of policy recommendation is directed in accordance with the results of FKK. The selected driving FKK is the existence of farmer groups, and the focus is to maintain the performance of the existing farmer groups. The method that can be used to maintain the performance of soybean farmer groups is by maintaining trust between the members and the group or between members and the other group members. Trust is considered as the primary means to maintain the performance of farmer groups since it is the most important social capital (Paul \& Seok, 2009; Elizabeth, 2007). In addition to increasing the trust between internal members, the encouragement of the external environment of the groups is also badly needed to maintain the performance of soybean farmer groups such as training and extension from the related agencies, especially in the case of soybean production and marketing activities of the local soybean itself. The existence of a synergistic relationship between the department of agriculture and soybean farmers will be very helpful to increase the soybean competitiveness in East Java.

The inhibiting Key Success Factor (FKK) is uncertainty of selling price, and the focus is on the stabilization of local soybean prices in order to compete with imported soybeans. This can be done by providing subsidies for soybean

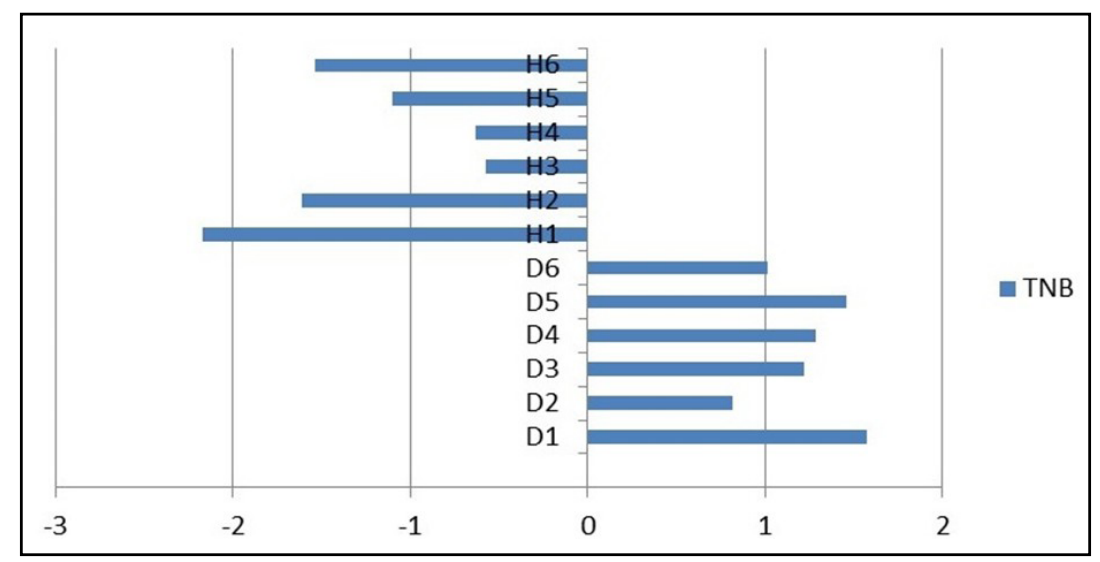

Source: Field survey 2013

Figure 1: Force field in the improvement of local soybean competitiveness in East Java. 
production facilities, determining the lowest retail price for soybean farmers to protect them, and setting the highest retail price to protect the soybean processing industry. In addition, the government and stakeholders also need to review the policy of soybean import if they want to make possibility of national self-sufficiency of soybeans (Joshi, Maharjan, 2007; Sudaryanto, 2001).

\section{Conclusion}

Performance of soybean farming in the country is not satisfactory considering some constraints in both economic institutional arrangement and farmers' traditional culture. The efforts to improve soybean farming are started from the local government's political will. Based on the results of FFA analysis, it can be seen that the key success factors (FKK) in the development of local soybean competitiveness is the existence of farmer groups; the focus is to maintain the performance of the existing farmer groups. Meanwhile, the inhibiting key success factors (FKK) is uncertainty of selling price, and the focus is on the stabilization of local soy prices in order to compete with imported soybeans. In addition, the reciprocal relationship is important in the cooperation between the institutions developing soybean farming in East Java, farmers, middlemen, farm stalls, government and agroindustry.

Corresponding author:

Ahmad Zainuri

Department of Economics, Faculty of Economics, University of Jember,

Jalan Kalimantan 37 Kampus Bumi Tegalboto, Jember, 68121 East Java, Indonesia

E-mail: zainuri.unej@gmail.com

\section{References}

[1] Adisarwanto. Budidaya Kedelai Tropika. Penebar Swadaya, Jakarta, 2008. ISBN 978-979-0023-550

[2] Ahmad, T. M. A., Tawang, A. Effect of Trade Liberalization on Agriculture in Malaysia: Commodity Aspect. CGPRT Working Paper Series 46, 1999. [Online]. Available: http://ageconsearch.umn.edu/bitstream/32694/1/wp990046.pdf [Accessed: 15 Dec. 2014].

[3] Budhi, G. S., Aminah, M. Self-sufficiency in Soybean: The Hope and the Reality. Forum Penelitian Agro Ekonomi. 2010, Vol. 28, No.1, p. 55-68. ISSN 0216-4361.

[4] Elizabeth, R. Penguatan dan Pemberdayaan Kelembagaan Petani Mendukung Pengembangan Agribisnis Kedelai. Proceedings of Pusat Analisis Sosial Ekonomi dan Kebijakan Pertanian, Bogor, 2007, p. 165-173. [Online]. Available: http://pse.litbang.pertanian.go.id/ind/pdffiles/ Pros_2007-C_2.pdf [Accessed: 2 Feb. 2015].

[5] Firdaus, M., Semaoen, M. I., Hanani, N. dan Syafrial. The Impact of Trade Liberalization on the Soybean Economic Performance in Indonesia. Journal of Basic and Applied Scientific Research, 2012. ISSN 2090-4304.

[6] Graham, B., Yu, T. H., Tokgoz, S., Elobeid, A. The Production and Price Impact of Biotech Corn, Canola, And Soybean Crops. AgBioForum, 2010, Vol. 13, No. 1, p. 25-52. ISSN 1522-936X.

[7] Handayani, D., Bantacut, T., Munandar, J. M., dan Budijanto, S. Simulasi Kebijakan Daya Saing Kedelai Lokal pada Pasar Domestik. Jurnal teknologi Industri Pertanian, 2009, Vol. 19, No. 1, p. 7-15. ISSN $0216-3160$.

[8] Huang, J., Rozelle, S. Trade Liberalization, Rising Import and China's Food Economy: The Case of Soybean. Report Submitted to the American Soybean Association, Freeman Spogli Institute (FSI) Stanford, 2004.

[9] Joshi, N. P., Maharjan, K. L. Assessment of Food Self-Sufficiency and Food Security Situation in Nepal. Journal of International Development and Cooperation, MPRA paper, 2007, Vol. 13, No. 1, p. 209-230. 
[10] Lee, J.W., Swagel, P. Trade Barriers And Trade flows Across Countries and Industries. International Finance Discussion Paper, 1994, Num. 476. [Online]. Available: http://www.federalreserve.gov/ pubs/ifdp/1994/476/ifdp476.pdf [Accessed: 22 Nov. 2014].

[11] Nuryanti S., Kustiari R. Meningkatkan Kesejahteraan Petani Kedelai dengan Kebijakan Tarif Optimal. Proceedings of Pusat Analisis Sosial Ekonomi dan Kebijakan Pertanian, Bogor, 2007. [Online]. Available: http://pse.litbang.pertanian.go.id/ind/pdffiles/Pros_2007-A_3.pdf [Accessed: 15 Dec. 2014].

[12] Paul, S. A., Seok, W. K. Social Capital: Prospects for a New Concept. Academy of Management, 2009, Vol. 27, No.1, p. 17 - 40. ISSN 0363-7425.

[13] Rante, Yohanis. Strategi Pengembangan Tanaman Kedelai Untuk Pemberdayaan Ekonomi Rakyat Di Kabupaten Keerom Provinsi Papua, Jurnal Manajemen dan Kewirausahaan, 2013, Vol. 15, No. 1, p. 75-88. ISSN 1411-1438.

[14] Reimer, A., Downey, A. S., Akridge, J. Market Segmentation Pratices of retail Corp Input Firms. International Food and Agribusiness Management Review, 2009, Vol. 12, No 1. ISSN 1096-7508.

[15] Song, B., Marchant, M. A., Reed M. R., Xu S. Competitive Analysis and Market Power of China's Soybean Import Market. International Food and Agribusiness Management Review, 2009, Vol.12, No. 1. ISSN 1096-7508.

[16] Sudaryanto, T., Rusastra, I. W., Saptana. Prespektif Pengembangan Ekonomi Kedelai di Indonesia. Forum Agro Ekonomi, 2001, Vol. 19, No. 1. p. 1-20. ISSN 0216-4361.

[17] Suradisastra, K. Strategi Pemberdayaan Kelambagaan Petani. Forum Penelitian Agro Ekonomi, 2008, Vol. 26, No. 2. p. 82 - 91. ISSN 0216-4361.

[18] Sumarno. Pemanfaatan teknologi genetika untuk peningkatan produksi kedelai. Pengembangan Inovasi Pertanian, 2010, Vol. 3, No. 4. p. 247 - 259. ISSN 1979-5378.

[19] Wahyuni, S. Kinerja Kelompok Tani dalam Sistem Usaha Tani Padi dan Metode pemberdayaannya. Jurnal Penelitian dan Pengembangan Pertanian, 2003, Vol. 22, No. 1. p. 1-8. ISSN 0214-4418.

[20] Zakaria, Amar K., Wahyuning K., Kustiari R. Analisis Daya Saing Komoditas Kedelai Menurut Agro Ekosistem: kasus di Tiga Provinsi di Indonesia, Jurnal Agro Ekonomi, 2010, Vol. 28, No. 1, p. 21 - 37. ISSN 0216-9053. 